\title{
МНОГООБРАЗИЕ
}

РЕЛИГИОЗНОГО ОПЫТА

\author{
М.И. Ясин
}

\section{УСТАНОВКИ В МЕЖЛИЧНОСТНЫХ ОТНОШЕНИЯХ У СОВРЕМЕННЫХ БУДДИСТОВ}

\begin{abstract}
Аннотация. Отечественные исследования по психологии буддизма в основном ведутся в философском ключе, предлагая разъяснения буддийских реалий и их анализ с точки зрения современной науки, однако в области эмпирической проверки мы видим явный дефицит. Наша работа вносит вклад в составление психологического «портрета» современных российских буддистов. Предметом исследования являются отличия коммуникативных установок современных буддистов Ваджраяны и атеистов. Найденные отличия рассматриваются как свидетельство успешного формирования определенных личностных особенностей при помощи целенаправленной буддийской практики. Установки в межличностных отношениях у буддистов исследовались с помощью тестовой методики Бойко на выборке в 70 человек и сравнивались с результатами, полученными в контрольной группе, 70 человек. Установки рассматриваются как психологический механизм, создающий определенную когнитивную и поведенческую направленность, который задает наиболее вероятный вектор поведения. У буддистов значимо ниже результаты по шкалам ответной агрессии и выше склонность воспринимать окружающих и происходящее в позитивном ключе. Целенаправленная буддистская практика может формировать и закреплять определенные установки, в данном случае - установки толерантного отношения к окружающим и позитивного настроя в межличностных взаимоотношениях.
\end{abstract}

Ключевые слова: психология религии, буддизм, установка, межличностные отношения, коммуникация, агрессия, духовные практики, психотехника, религии-экспаты, позитивное отношение.

Abstract. Russian researches of Buddhism psychology are mostly philosophical and offer explanations of Buddhist realities and their analysis from the point of view of modern science, however, there is very little that has been done in the sphere of their empirical verification. The present research intends to contribute to the creation of the 'psychological portrait' of contemporary Russian Buddhists. The subject of the research is distinguished features of communication stereotypes demonstrated by contemporary Vajrayāna Buddhists and atheists. These distinguished features are viewed as a proof of successful development of certain personal traits through well-directed Buddhist's practice. Attitudes demonstrated by Buddhists in their interpersonal relations are studied using Boyko's inventory. 70 Buddhists were studied. The results of their tests were compared to the results demonstrated by the control group of another 70 people. Within the framework of the present research attitudes are viewed as a psychological mechanism creating certain cognitive and behavioral orientation which, in its turn, sets the most probable vector of one's behavior. Buddhists demonstrate lower levels of aggression in response to aggresive actions and more positive attitude to others and events. Thus, well-directed Buddhist practice can develop and fortify certain attitudes, in thsi case - tolerance towards others and a positive attitude to interpersonal relations.

Key words: aggression, communication, interpersonal relationships, attitude, Buddhism, psychology of religion, spiritual practices, psychotechnics, expatriate religions, positive attitude.

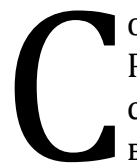

овременный буддизм Ваджраяны пришел в Россию с запада в 90-е годы и занял позиции среди религий-экспатов. Он стал популярен в основном среди городских интеллектуалов, офисных сотрудников и творческой интеллигенции. Современный Буддизм старательно отмежевывается от «религий» как таковых, считая себя системой методов саморазвития. Основной аргумент буддизма состоит в том, что он не опирается на веру, как остальные мировые религии.
Так или иначе, буддизм является упорядоченной мировоззренческой системой, предлагающей своим последователям определенные установки, что свойственно и религиям.

Под установкой мы понимаем, согласно концепции Д. Н. Узнадзе психологический механизм, определяющий направленность и избирательную активность поведения человека [1]. Установка не обязательно предполагает реализацию в поведении, это утверждение хорошо иллюстрирует так 
называемый «Парадокс Ла Пьера» [2]. Однако психологи сходятся в том, что установка задает наиболее вероятный вектор поведения.

Психологические исследования религиозных установок чаще всего выполняются в предметном ключе: исследуется отношение к социальным явлениям или объектам, тенденции действовать определенным образом, обусловленные осознаваемыми или неосознаваемыми причинами. Это отношение к другим конфессиям $[3,4]$, так называемым «новым ценностям»- сексуальности, гомосексуальным семьям $[5,6]$, суррогатному материнству, использованию стволовых клеток [7].

Но исследовательскую задачу можно ставить шире, существуют более общие установки, определяющие целую сферу человеческой жизни, например, установки в общении или установки относительно трудовой деятельности. Такой подход оправдан открытием феномена агрегации: установку проще выявить в ряде действий человека, но невозможно точно зафиксировать по одному поступку. В последнем случае роль ситуативных и случайных факторов слишком высока. Согласно формулировке А. А. Райна, принцип агрегации заключается в том, что действие установки «становится более четким и очевидным, когда мы рассматриваем личность и поведение в целом, а не какой-либо отдельный поступок» [8, С. 44].

По мнению Л. А. Киркпатрика роль религии в жизни человека сводится к трем основным функциям: 1) обеспечить смысл жизни; 2) помогать справляться с различными жизненными ситуациями; 3) создать чувство доверия к людям [9]. Второй пункт включает ситуации коммуникации, а последний - напрямую касается сферы отношений человека и окружающих. Религии пытаются формировать ряд определенных установок касательно взаимоотношений с людьми. Буддизм предлагает желать «блага всем живым существам» и относится к каждому существу, как к будде. Эти регулярно повторяемые формулы имеют целью сформировать установку на большую открытость и любовь к людям.

Мы поставили задачу выяснить: действительно ли Буддизму удается сформировать установку на более доброжелательное отношение к окружающим? Есть ли статистическая разница в коммуникативных установках регулярно практикующих буддистов и не-буддистов?

Для ответа на эти вопросы мы использовали опросник «Определение деструктивных установок в межличностных отношениях» В.В.Бойко [10], опросник «Инспирит» Дж. Касса [10] небольшую и авторскую анкету. Методика Бойко позволяет измерить отрицательные установки в общении по нескольким параметрам: уровень априорной недоброжелательности, однозначность и резкость выводов относительно людей, ответная реакция на агрессию, недовольство окружающими и жизнью в целом, скрытая кумулятивная агрессия. Тест Касса позволяет определить, насколько живы духовные переживания, непосредственный духовный опыт. Второй тест и анкета служили цели показать, насколько участвовавшие в исследовании буддисты глубоко погружены в духовную жизнь и буддистские практики.

Выборку составили 70 буддистов, регулярно посещающих буддистский центр «Алмазного пути» и выполняющих буддистские практики не реже 1 раза в неделю. Общий стаж буддийской практики у испытуемых от 4 до 25 лет, средний стаж - 10 лет. Контрольная группа представлена 70-ю участниками, не относящими себя к буддизму или какойлибо религии. Основная и контрольная группы выровнены по полу и возрасту, возраст испытуемых - от 19 до 55 лет, соотношение мужчин и женщин $1 / 2$.

По методике Дж. Касса средний балл у буддистов составил 3,4; медиана 3,6; дисперсия 0,18. В контрольной группе: средний балл 2,1; медиана 2,1; дисперсия 0,45. Результаты показывают, у буддистов в данной выборке высокая степень духовной погруженности и живости духовных переживаний при большей однородности группы (дисперсия).

Сравнение по методике «Определение деструктивных установок» производилось методом двухвыборочного Т-критерия Стьюдента, для выборок с различными дисперсиями.

По совокупному результату теста не было выявлено статистически значимых отличий между буддистами и контрольной группой (t-статистика $=-0,51$, при $\mathrm{P}<=0,61)$. Так же не было отмечено значимой разницы по ряду шкал. Шкала «Завуалированная жестокость» показывает общую настороженность при общении и восприятие людей как источник возможной угрозы. По этой шкале не было отмечено различий (t-статистика $=-1,52$, при $\mathrm{P}<=0,13)$. Шкала «Жесткость по отношению к людям» отражает тенденцию не скрывать и не смягчать своих негативных оценок окружающих, а так же делать выводы о них резкие, однозначные выводы и затем придерживаться этого отношения к человеку. Здесь так же значимых отличий не обнаружено (t-статистика $=0,29$, при $\mathrm{P}<=0,77$ ). Шкала «Негативный опыт в общении» отражает, насколько человек оценивает свой опыт общения, 


\section{Психология и психотехника 5(92) • 2016}

как удачный, насколько ему «повезло» с окружающими его людьми. Здесь различий не обнаружено (t-статистика $=0,91$, при $\mathrm{P}<=0,36$ ).

У буддистов ниже оказались баллы по шкале «Обоснованный негативизм» (t-статистика $=-2,49$, при $\mathrm{P}<=0,01)$. Эта шкала отражает умение дать отпор при ущемлении своих прав, ответить на агрессию. Шкала измеряет установку на так называемое ассертивное поведение - «конструктивную агрессию». Исследователями оно рассматривается как один из инструментов социальной адаптации - «конструктивная агрессия», в то время как агрессия сама по себе увеличивает дезадаптивное поведение [12]. Однако низкий балл по шкале показывает сдерживание агрессивных ответов на внешнее воздействие, повышение сил самоконтроля. Данную установку можно выразить формулой «непротивление злу насилием». В философии буддизма гнев относится к «мешающим чувствам», которые буддисты рекомендуют отслеживать, наблюдать, как они приходят и уходят, при этом не спешить с действиями [13, С. 24-26]. Результаты измерений показывают, данная установка свойственна многим буддистам и довольно хорошо укрепилась в умах тех, кто регулярно практикует буддистские методы.

Статистически значимо оказалось отличие по шкале «Недовольство жизнью», которая показывает общую установку на восприятие своей жизни и окружающих людей в негативном ключе, стремление жаловаться на жизнь. У буддистов баллы значительно ниже, чем в контрольной группе (t-статистика $=-3,72$, при $\mathrm{P}<=0,0003)$. Буддисты стремиться к «необусловленному счастью», то есть счастью, проистекающему из свойств ума, но не зависящему от внешних переменчивых причин. Хорошо данная формула отражена в словах буддолога и учителя буддизма Е. Леонтьевой; «...единственной задачей Будды было помочь людям найти путь к такому счастью, которое не нуждается во внешних источниках» [14, C.53]. Мы отмечаем, субъективное восприятие буддистами окружающего мира и людей действительно оказывается более позитивным, что зафиксировано при помощи данной шкалы теста. Регулярная практика буддизма позволяет сформировать установку на позитивное восприятие людей и актов коммуникации, свободное от обвинений других и недовольства окружающими в целом.

Одной из причин обращения к современному буддизму является наличие в нем психологических методов [15], которые оказываются действенными и реально могут повлиять на восприятие событий и других людей, что влечет за собой повышение уровня субъективного благополучия. Буддистские практики порой называют одной из древнейших «психотехник» [15]. Это не первый опыт обращения к восточным духовным практикам в истории, интерес к ним, в том числе среди психологов, уже имел место на волне развития гуманистической психологии [16].

Наше исследование показало, что буддистская практика может формировать установки терпимости к окружающим и позитивный настрой в межличностных взаимоотношениях. Мы полагаем, формирование подобных установок имеет систематических характер и является результатом целенаправленной практики предлагаемых буддизмом методов, так как сформированные качества явно соотносятся с тезисами, выдвигаемыми буддизмом.

Полученные результаты позволяют говорить об установке на сдерживание ответной реакции на нападки извне, контролирование агрессии (шкала «Обоснованный негативизм») и тенденцию воспринимать окружающих и происходящее в позитивном оптимистическом ключе (шкала «Недовольство жизнью»).

Отечественные исследования по психологии буддизма в основном ведутся в философском ключе, предлагая разъяснения буддийских реалий и их анализ с точки зрения современной науки, однако в области эмпирической проверки мы видим явный дефицит. Наша работа вносит вклад в составление психологического «портрета» современных российских буддистов.

\section{Библиография:}

1. Узнадзе Д. Н. Психология установки. СПб. : Питер. 2001. 416 с.

2. Копец Л. В., Классические эксперименты в психологии / Киев, 2010. 230 с.

3. LaBouff J. P., Rowatt W. C., Johnson M. K., Finkle C., Differences in Attitudes Toward Outgroups in Religious and Nonreligious Contexts in a Multinational Sample: A Situational Context Priming Study // International Journal for the Psychology of Religion. 2012. Vol. 22 (1). P. 1-9.

4. Van Tongeren D. R., Hakim S., Hook J. N., Johnson K. A., Green J. D., Hulsey T. L., Davis D. E., Toward an Understanding of Religious Tolerance: Quest Religiousness and Positive Attitudes Toward Religiously Dissimilar Others // International Journal for the Psychology of Religionpages. 2015. Vol. 25 (4). P. 1-13.

5. Bernard E., Whitley Jr., Religiosity and Attitudes Toward Lesbians and Gay Men: A Meta-Analysis // International Journal for the Psychology of Religion. 2009. Vol. 19 (1). P. 21-38. 


\section{Многообразие религиозного опыта}

6. Brelsford G. M., Luquis R.,Murray-Swank N. A., College Students' Permissive Sexual Attitudes: Links to Religiousness and Spirituality // International Journal for the Psychology of Religion. 2011. Vol.21 (2). P. 127-136

7. Nielsen M. E., Williams, J., Randolph-Seng, B., Religious Orientation, Personality, and Attitudes About Human Stem Cell Research // International Journal for the Psychology of Religion. 2009. Vol. 19 (2). P. 81-91.

8. Реан А. А., Социальные установки как фактор делинквентного поведения несовершеннолетних // Вестник Балтийского федерального университета им. И. Канта. Серия: Филология, педагогика, психология. 2015. № 11. С. 44-54.

9. Kirkpatrick L. A. Toward an evolutionary psychology of religion and personality // Journal of Personality. 1999. № 67. P. 921952.

10. Бойко В. В.,Энергия эмоций в общении: взгляд на себя и на других. М. : Информационно-издательский дом «Филинъ», 1996. 472 с.

11. Kass J. D., Friedman R., Leserman J., Zuttermeister P., Benson H., Health outcomes and a new measure of spiritual experience // Journal of Scientific Study of Religion. 1991. Vol. 30. P. 203-211.

12. Овсяник О. А., Зотова Л. Э., Шульга Т. И., Сидячева Н. В., Проявление агрессивного поведения в процессе социальнопсихологической адаптации личности // Современные исследования социальных проблем (электронный научный журнал). 2015. № 1 (45). с. 36-47.

13. Ринпоче Дж. (лама), Расти свободным. К. : Диалог Пресс, 2009. 127 с.

14. Леонтьева, Е., Путеводитель по буддизму. Иллюстрированная Энциклопедия. М. : Эксмо, 2012. 258 с.

15. Уланов М. С., О причинах распространения буддизма на западе в эпоху глобализации // Вестник Волгоградского государственного университета. Серия 7: Философия. Социология и социальные технологии. 2008. № 2. С. 68-72.

16. Ясин М. И. Поворот психологической мысли в 60-е годы XX столетия // Сборники конференций НИЦ Социосфера. 2012. № 7. C. 12-14.

\section{References (transliterated):}

1. Uznadze D. N. Psikhologiya ustanovki. SPb. : Piter. 2001. $416 \mathrm{~s}$.

2. Kopets L. V., Klassicheskie eksperimenty v psikhologii / Kiev, 2010. 230 s.

3. LaBouff J. P., Rowatt W. C., Johnson M. K., Finkle C., Differences in Attitudes Toward Outgroups in Religious and Nonreligious Contexts in a Multinational Sample: A Situational Context Priming Study // International Journal for the Psychology of Religion. 2012. Vol. 22 (1). P. 1-9.

4. Van Tongeren D. R., Hakim S., Hook J. N., Johnson K. A., Green J. D., Hulsey T. L., Davis D. E., Toward an Understanding of Religious Tolerance: Quest Religiousness and Positive Attitudes Toward Religiously Dissimilar Others // International Journal for the Psychology of Religionpages. 2015. Vol. 25 (4). P. 1-13.

5. Bernard E., Whitley Jr., Religiosity and Attitudes Toward Lesbians and Gay Men: A Meta-Analysis // International Journal for the Psychology of Religion. 2009. Vol. 19 (1). P. 21-38

6. Brelsford G. M., Luquis R.,Murray-Swank N. A., College Students' Permissive Sexual Attitudes: Links to Religiousness and Spirituality // International Journal for the Psychology of Religion. 2011. Vol.21 (2). P. 127-136

7. Nielsen M. E., Williams, J., Randolph-Seng, B., Religious Orientation, Personality, and Attitudes About Human Stem Cell Research // International Journal for the Psychology of Religion. 2009. Vol. 19 (2). P. 81-91.

8. Rean A. A., Sotsial'nye ustanovki kak faktor delinkventnogo povedeniya nesovershennoletnikh // Vestnik Baltiiskogo federal'nogo universiteta im. I. Kanta. Seriya: Filologiya, pedagogika, psikhologiya. 2015. № 11. S. 44-54.

9. Kirkpatrick L. A. Toward an evolutionary psychology of religion and personality // Journal of Personality. 1999. № 67. R. 921952.

10. Boiko V. V.,Energiya emotsii v obshchenii: vzglyad na sebya i na drugikh. M. : Informatsionno-izdatel'skii dom «Filin”», 1996. $472 \mathrm{~s}$.

11. Kass J. D., Friedman R., Leserman J., Zuttermeister P., Benson H., Health outcomes and a new measure of spiritual experience // Journal of Scientific Study of Religion. 1991. Vol. 30. P. 203-211.

12. Ovsyanik O. A., Zotova L. E., Shul'ga T. I., Sidyacheva N. V., Proyavlenie agressivnogo povedeniya v protsesse sotsial'nopsikhologicheskoi adaptatsii lichnosti // Sovremennye issledovaniya sotsial'nykh problem (elektronnyi nauchnyi zhurnal). 2015. № 1 (45). s. 36-47.

13. Rinpoche Dzh. (lama), Rasti svobodnym. K. : Dialog Press, 2009. 127 s.

14. Leont'eva, E., Putevoditel' po buddizmu. Illyustrirovannaya Entsiklopediya. M. : Eksmo, $2012.258 \mathrm{~s}$.

15. Ulanov M. S., O prichinakh rasprostraneniya buddizma na zapade v epokhu globalizatsii // Vestnik Volgogradskogo gosudarstvennogo universiteta. Seriya 7: Filosofiya. Sotsiologiya i sotsial'nye tekhnologii. 2008. № 2. S. 68-72.

16. Yasin M. I. Povorot psikhologicheskoi mysli v 60-e gody XX stoletiya // Sborniki konferentsii NITs Sotsiosfera. 2012. S. 12-14. 